\title{
Concentrations of 137Cs radiocaesium in the organs and tissues of low-dose-exposed wild Japanese monkeys
}

Toshinori Omi ( $\nabla$ toshinoriomi@gmail.com )

Nihon Jui Seimei Kagaku Daigaku https://orcid.org/0000-0001-9303-2746

\section{Sachie Nakiri}

Nihon Jui Seimei Kagaku Daigaku

\section{Setuko Nakanishi}

Conservation and Animal Welfare

\section{Naomi Ishii}

Nihon Jui Seimei Kagaku Daigaku

\section{Taiki Uno}

Nihon Jui Seimei Kagaku Daigaku

Fumiharu Konno

Fukushima-Mirai Agricultural Cooporative

\section{Takeshi Inagaki}

Jichi lka Daigaku

\section{Atsushi Sakamoto \\ Jichi Ika Daigaku}

\section{Masayuki Shito}

Nihon Jui Seimei Kagaku Daigaku

\section{Chihiro Udagawa}

Nihon Jui Seimei Kagaku Daigaku

\section{Naomi Tada}

Nihon Jui Seimei Kagaku Daigaku

Kazuhiko Ochiai

Nihon Jui Seimei Kagaku Daigaku

\section{Takuya Kato}

Nihon Jui Seimei Kagaku Daigaku

\section{Yoshi Kawamoto}

Nihon Jui Seimei Kagaku Daigaku

\section{Shuichi Tsuchida}

Nihon Jui Seimei Kagaku Daigaku

\section{Shin-ichi Hayama}

Nihon Jui Seimei Kagaku Daigaku

\section{Research note}

Keywords: Japanese monkeys, Fukushima Daiichi Nuclear disaster, caesium, radioactive contamination

Posted Date: January 22nd, 2020 
DOI: https://doi.org/10.21203/rs.2.21592/v1

License: (c) This work is licensed under a Creative Commons Attribution 4.0 International License. Read Full License

Version of Record: A version of this preprint was published at BMC Research Notes on March 2nd, 2020. See the published version at https://doi.org/10.1186/s13104-020-04972-z. 


\section{Abstract}

Objectives

Following the massive earthquake that struck eastern Japan on March 11, 2011, a large amount of radioactive material was released into the environment from the damaged reactor of the Fukushima Daiichi Nuclear Power Plant (FDNPP). After the FDNPP accident, radiocaesium was first detected in muscle samples from wild Japanese monkeys exposed to radioactive materials, and haematologic effects, changes in head size, and delayed body weight gain were also reported, but little is known about the distribution of 137Cs in the organs and tissues of wild Japanese monkeys.

Results

We detected the 137Cs in various organ and tissue samples of 10 wild Japanese monkeys inhabiting the forested areas of Fukushima City that were captured between July and August 2012.Among muscle, brain, heart, kidney, liver, lung, and spleen, muscle exhibited the highest and the brain the lowest 137Cs concentration. The concentration (mean \pm SD) of137Cs in muscle, brain, heart, kidney, liver, lung, and spleen was $77 \pm 66,26 \pm 22,41 \pm 35,49 \pm 41,41 \pm 38,53 \pm 41$, and $53 \pm 51 \mathrm{~Bq} / \mathrm{kg}$, respectively. These results can help us understand the biological effects of long-term internal radiation exposure in non-human primates.

\section{Introduction}

Following the massive earthquake that struck eastern Japan on March 11, 2011, a large amount of radioactive material was released into the environment from the damaged reactor of the Fukushima Daiichi Nuclear Power Plant (FDNPP) $[1-4]$. To date, the effects of exposure to the radioactive materials released from the FDNPP have been investigated not only in humans [5, 6] but also in blue butterflies [7], cattle [8, 9], monkeys [10-13], fish [14], birds [15], pigs [16], and wild boar [17].

The Japanese monkey, one of the world's northernmost wild primates, is endemic to Japan and has a life span of more than 20 years [18]. Japanese monkeys usually form troops consisting of 50-100 individuals of one maternal lineage, and each troop occupies a home range spanning approximately $4-27 \mathrm{~km}^{2}$ in snowy areas [19-21]. The monkeys feed primarily on plant leaves and fruits but also eat insects and other small animals [22]. We began a research project in 2011 to examine the health effects of long-term radiation exposure on wild Japanese monkeys inhabiting the forested areas surrounding Fukushima City, which is located $70 \mathrm{~km}$ from the FDNPP, and we anticipate that our findings will provide valuable data and insights. In addition, data from non-human primates-the closest taxonomic relatives to humans-should make a notable contribution to future research examining the health effects of radiation exposure in humans. In our previous study, we detected high levels of radiocaesium in muscle [10] and reported haematologic effects [11] as well as changes in head size and delayed body weight gain in wild Japanese monkeys [12] after the FDNPP disaster. In the present study, we determined the distribution of ${ }^{137} \mathrm{Cs}$ in various organs and tissues of wild Japanese monkeys inhabiting the forested areas surrounding Fukushima City that were captured between July and August 2012.

\section{Materials And Methods}

Animals

Samples of muscle, brain, heart, kidney, liver, lung, and spleen were collected from 10 Japanese monkeys (Macaca fuscata) captured between July and August 2012 from the forested areas around Fukushima City. These monkeys were used in a previously reported study to determine the concentrations of ${ }^{134} \mathrm{Cs}$ and ${ }^{137} \mathrm{Cs}$ in the muscles and characterize 
the changes in concentration over time as well as their relationship with soil contamination levels [12]. Organ and tissue samples were stored frozen at $-30^{\circ} \mathrm{C}$ after 2012 until they were used in the present study. The age of each animal was estimated from the status of tooth eruption, as described by Iwamoto et al. [23], to divide the animals into the following age groups: juveniles ( $0-3$ years), subadults ( $4-5$ years), and adults ( $\geq 6$ years).

Radioactivity measurements

Samples of skeletal muscle, brain, heart, kidney, liver, lung, and spleen were analysed using a germanium semiconductor spectrometer (Canberra, GC2020-7500SL-2002CSL, Meriden, CT) equipped with a Nal (T1) scintillation detector (Atometex, AT1320A, Minsk, Belarus). Data were corrected to the background radiation dose of the measurement environment on an as-needed basis. ${ }^{137} \mathrm{Cs}$ was detected based on 661.6-keV gamma-ray energy. Collected samples were stored frozen at $-30{ }^{\circ} \mathrm{C}$ until radioactivity measurements. This method of measurement is the same as that used in our previous study [12]. The radiocaesium radioactivity level was adjusted to the value on the day of capture based on physical half-life. The limit of detection was $5 \mathrm{~Bq} / \mathrm{kg}$.

Statistical analysis

Differences in mean ${ }^{137} \mathrm{Cs}$ concentration between groups were analysed by one-way ANOVA using SPSS, ver. 19 (IBM Corp., Armonk, NY, USA).

\section{Results And Discussion}

Table 1 and Fig. 1 show the concentrations of ${ }^{137} \mathrm{Cs}$ in skeletal muscle and various organ samples obtained from 10 Japanese monkeys captured between July and August 2012. The monkeys inhabited the forested areas surrounding Fukushima City, which is located $70 \mathrm{~km}$ from the FDNPP. The average ${ }^{137} \mathrm{Cs}$ concentration in the skeletal muscles and internal organs ranged from 26 to $77 \mathrm{~Bq} / \mathrm{kg}$. Among the skeletal muscle, brain, heart, kidney, liver, lung, and spleen, muscle exhibited the highest and the brain the lowest ${ }^{137} \mathrm{Cs}$ concentration. The mean $( \pm \mathrm{SD}){ }^{137} \mathrm{Cs}$ concentration in the muscle, brain, heart, kidney, liver, lung, and spleen was $77 \pm 66,26 \pm 22,41 \pm 35,49 \pm 41,41 \pm 38,53 \pm 41$, and $53 \pm$ $51 \mathrm{~Bq} / \mathrm{kg}$, respectively. There were no significant differences in mean ${ }^{137} \mathrm{Cs}$ concentration between groups, as determined by one-way ANOVA. The ratio of the concentration of ${ }^{137} \mathrm{Cs}$ in each organ to that in muscle $\left({ }^{137} \mathrm{Cs}\right.$ in each organ $/{ }^{137} \mathrm{Cs}$ in muscle) was $0.34 \pm 0.06,0.53 \pm 0.13,0.64 \pm 0.14,0.52 \pm 0.14,0.70 \pm 0.26$, and $0.66 \pm 0.15$ for the brain, heart, kidney, liver, lung, and spleen, respectively.

\section{Table 1. Concentration of ${ }^{137} \mathrm{Cs}$ in various organs and tissues of Japanese wild monkeys.}




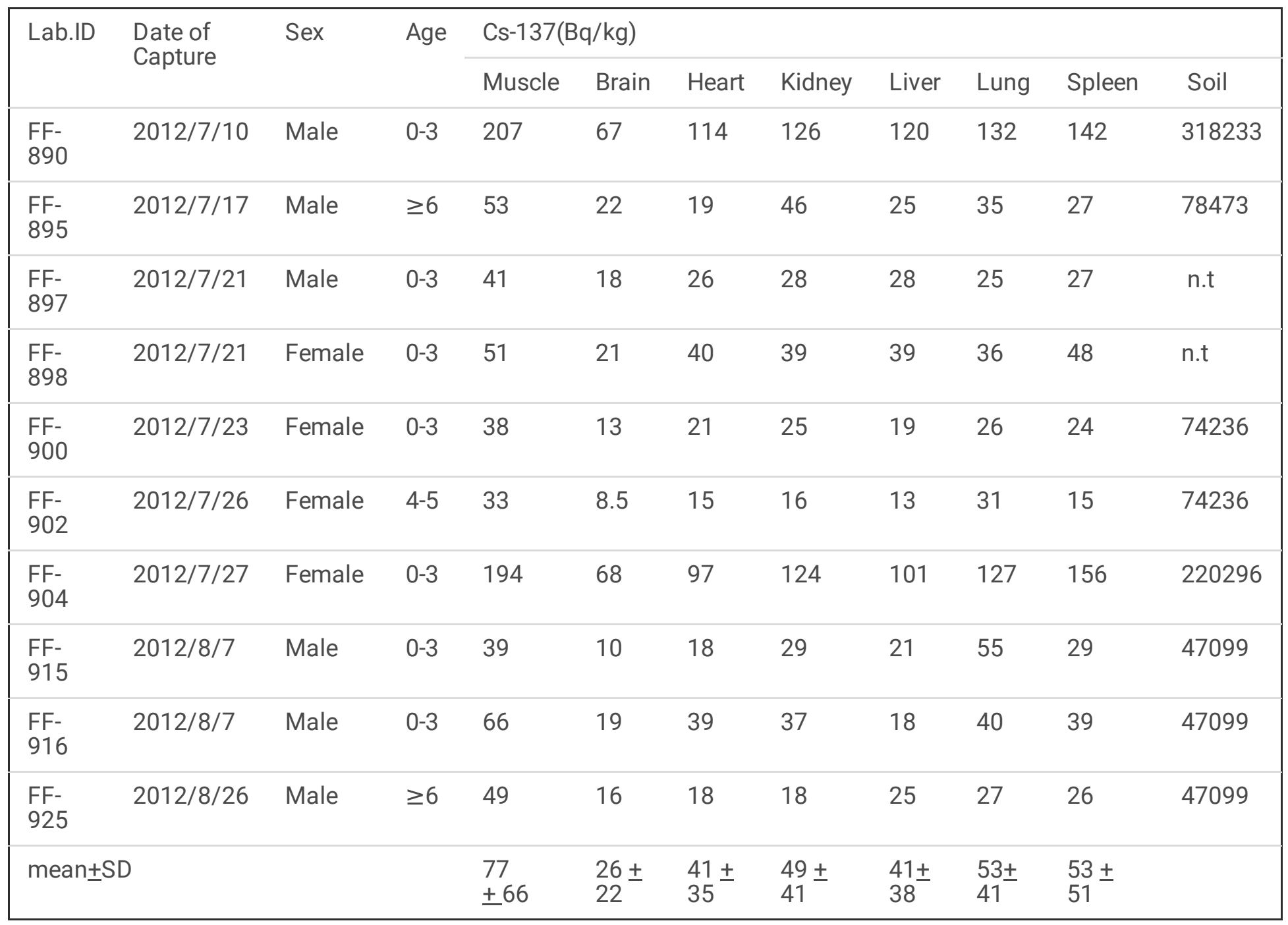

In this study, we found the highest concentration of radiocaesium in the skeletal muscle and lowest concentration in the brain of Japanese wild monkeys inhabiting forested areas surrounding Fukushima City. These findings agree with those of previous studies in cattle [8,9] and wild boar [17]. Similar results in wild Japanese monkeys were recently reported by Urushibara et al. [26]. However, the order of the relative ${ }^{137} \mathrm{Cs}$ concentration of the internal organs seemed to be slightly different between species. In particular, the lung and spleen showed high ${ }^{137} \mathrm{Cs}$ concentrations in Japanese monkeys.

The muscle radiocaesium concentration in the monkeys correlated significantly with the level of soil contamination at each capture location [12]. The ${ }^{137}$ Cs concentration in organs of two individuals, labelled FF-890 and FF-904, was higher than that in other individuals, which was related to the soil concentration of radiocaesium.

These data regarding the distribution of ${ }^{137} \mathrm{Cs}$ in the organs and tissues of Japanese monkeys captured in the areas surrounding Fukushima City will enhance our understanding of the biological effects of long-term internal radiation exposure. Continued monitoring of Japanese wild monkeys exposed to radioactive materials following the FDNPP accident would help in understanding the biological effects of long-term internal radiation exposure to the natural world.

Limitations

Continued monitoring of Japanese wild monkeys exposed to radioactive materials following the FDNPP accident would help in understanding the variation of the ${ }^{137} \mathrm{Cs}$ concentration among the organs of the body and its biological effects under long-term internal exposure. 


\section{Abbreviations}

FDNPP

Fukushima Daiichi Nuclear Power Plant

Cs

caesium

ANOVA

analysis of variance

\section{Declarations}

\section{Ethics approval and consent to participate}

Carcasses of Japanese monkeys were provided by Fukushima City. Monkeys were culled as a measure against crop damage with the permission of the governor of Fukushima Prefecture, according to the Fukushima Japanese Monkey Management Plan, which was established based on the Wildlife Protection and Hunting Management Law. Monkeys were captured using box traps and killed with a gun by licensed hunters at the request of Fukushima City. The capture and killing method was in accordance with the guidelines of the management plan stated above and should not be an ethical concern. The killing method was also in accordance with guidelines published by the Primate Research Institute, Kyoto University [24,25]. Japanese monkeys inhabiting the research area are not listed as an endangered species on the Japanese Red List, as revised by the Ministry of the Environment in 2012 [26]. This study was performed without gathering new tissue but rather by using samples from our previous study [10-12].

\section{Consent for publication}

Not applicable.

\section{Availability of data and materials}

Only publicly available data were analysed in this paper. The final datasets and code are available from the corresponding author upon request.

\section{Competing interests}

The authors declare that they have no competing interests.

\section{Funding}

This study was supported by the Science Research Promotion Fund from the Promotion and Mutual Aid Corporation for Private Schools of Japan.

\section{Contributions}

Conceived and designed the experiments: TO, TI, AS, YK, ST, SH. Performed the experiments: SN, SN, NI, TU, FK, MS, CU, NT, KO, TK. Analysed the data: TO. Wrote the paper: TO, SH. All authors read and approved the final manuscript.

Correspondence to Toshinori Omi

\section{Acknowledgements}


The present study was made possible by the cooperation of Fukushima City. The authors would like to express their sincere thanks to all those involved in this study. We would also like to express our deepest gratitude to Ms. Ayano Matsuda, Ms. Miki Yoshikawa, and other members of the Department of Wildlife Medicine and Department of Basic Science, Nippon Veterinary and Life Science University, for their critical assistance in the study.

\section{References}

1. Kinoshita N, Sueki K, Sasa K, Kitagawa J, Ikarashi S, Nishimura T, Wong YS, et al. Assessment of individual radionuclide distributions from the Fukushima nuclear accident covering central-east Japan. Proc Natl Acad Sci USA. 2011;108:19526-9.

2. Yasunari TJ, Stohl A, Hayano RS, Burkhart JF, Eckhardt S, Yasunari T. Cesium-137 deposition and contamination of Japanese soils due to the Fukushima nuclear accident. Proc Natl Acad Sci USA 2011;108:19530-4.

3. Garnier-Laplace J, Beaugelin-Seiller K, Hinton TG. Fukushima wildlife dose reconstruction signals ecological consequences. Environ Sci Technol. 2011.5;45:5077-8.

4. Buesseler K, Aoyama M, Fukasawa M. Impacts of the Fukushima nuclear power plants on marine radioactivity. Environ Sci Technol. 2011;45:9931-5.

5. Yasumura S, Hosoya M, Yamashita S, Kamiya K, Abe M, Akashi M, Kodama K, et al. Fukushima Health Management Survey Group.Study protocol for the Fukushima health management survey. J Epidemiol. 2012;22:375-83.

6. Hasegawa A, Tanigawa K, Ohtsuru A, Yabe H, Maeda M, Shigemura J, Ohira T,et al. Health effects of radiation and other health problems in the aftermath of nuclear accidents, with an emphasis on Fukushima. Lancet. 2015;386:479-88.

7. Hiyama A, Nohara C, Kinjo S, Taira W, Gima S, Tanahara A, Otaki JM. The biological impacts of the Fukushima nuclear accident on the pale grass blue butterfly. Sci Rep. 2012;2:570.

8. Fukuda T, Kino Y, Abe Y, Yamashiro H, Kuwahara Y, Nihei H, Sano Y, et al. Distribution of artificial radionuclides in abandoned cattle in the evacuation zone of the Fukushima Daiichi nuclear power plant. PLoS One. 2013;8:e54312.

9. Okada K, Sato I, Deguchi Y, Morita S, Yasue T, Yayota M, Takeda K, et al. Distribution of radioactive cesium in edible parts of cattle. Anim Sci J 2013;84:798-801.

10. Hayama S, Nakiri S, Nakanishi S, Ishii N, Uno T, Kato T, Konno F,et al. Concentration of radiocesium in the wild Japanese monkey (Macaca fuscata) over the first 15 months after the Fukushima Daiichi nuclear disaster. PLoS One. 2013;8(7):e68530.

11. Ochiai K, Hayama S, Nakiri S, Nakanishi S, Ishii N, Uno T, Kato T, et al. Low blood cell counts in wild Japanese monkeys after the Fukushima Daiichi nuclear disaster. Sci Rep. 2014;4:5793.

12. Hayama SI, Tsuchiya M, Ochiai K, Nakiri S, Nakanishi S, Ishii N, Kato T, et al. Small head size and delayed body weight growth in wild Japanese monkey fetuses after the Fukushima Daiichi nuclear disaster. Sci Rep. 2017;7:3528.

13. Urushihara Y, Suzuki T, Shimizu Y, Ohtaki M, Kuwahara Y, Suzuki M, Uno T, et al. Haematological analysis of Japanese macaques (Macaca fuscata) in the area affected by the Fukushima Daiichi Nuclear Power Plant accident. Sci Rep. 2018;8:16748.

14. Iwata K, Tagami K, Uchida S. Ecological half-lives of radiocesium in 16 species in marine biota after the TEPCO's Fukushima Daiichi nuclear power plant accident. Environ Sci Technol. 2013;47:7696-703.

15. Bonisoli-Alquati A, Koyama K, Tedeschi DJ, Kitamura W, Sukuzi H, Ostermiller S, Arai E, et al. Abundance and genetic damage of barn swallows from Fukushima. Sci Rep. 2015;5:9432. 
16. Ohmori H, Sasaki Y, Tajima K, Katsumata M. Radioactive caesium concentrations in pigs fed brown rice contaminated by the Tokyo Electric Power Company Fukushima Daiichi nuclear power plant. Livestock Science. 2014;156-160.

17. Tanoi K, Uchida K, Doi C, Nihei N, Hirose A, Kobayashi NI, Sugita R, et.al. Investigation of radiocesium distribution in organs of wild boar grown in litate, Fukushima after the Fukushima Daiichi nuclear power plant accident $J$ Radioanal Nucl Chem. 2016;307:741-746.akahata Y, Huffman MA, Norikoshi K, Suzuki H. Reproductive parameters of female Japanese macaques: Thirty years data from the arashiyama troops, Japan. Primates. 1992; 33: 33-47.

18. Wada K, Ichiki Y. Seasonal Home Range Use by Japanese Monkeys in the Snowy Shiga Heights. Primates. 1980; 21: 468-483.

19. Imaki H, Koganezawa M, Okumura T, Maruyama N. Home range and seasonal migration of Japanese monkeys in Nikko and Imaichi, central Honshu, Japan. Biosphere Conservation. 2000;3: 1-16.

20. Enari H, Sakamaki-Enari H.Resource use of Japanese of Japanese macaques in heavy snowfall snowfall areas: implications for habitat management. Primates. 2013;54:259-69.

21. Primate Research Institute, Kyoto University Guideline for fieled reserch for non-human primates. Available: http://www.pri.kyoto-u.ac.jp/research/guide-e2008.html Accessed 2013 Jun 8.

22. Iwamoto $M$, Watanabe $T$, Hamada $Y$.Eruption of permanent teeth in Japanese monkeys (Macaca fuscata). Primate Res. 1987. 3: 18-28 (in Japanese with English summary)..

23. International Primatological Society Guidelines for the use of non-human primates. Available: http://www.internationalprimatologicalsociety.org/docs/IPS\%20ethical\%20 guidelines \%20 FINAL.pdf Accessed 2013 Jun 8.

24. Japanese Ministry of Environment .Japanese Red List. 2012. http:// www.env.go.jp/en/nature/biodiv/reddata.html Accessed 2013 Jun 8.

25. Urushihara Y, Suzuki T, Shimizu Y, Suzuki M, Kuwahara Y, Kino Y, Sekine T, et.al. Radiocaesium distribution in Japanese macaques within the evacuation zone around the TEPCO Fukushima Daiichi Nuclear Power Plant. KEK Proceedings (Web) 2017(Japanese).

\section{Figures}




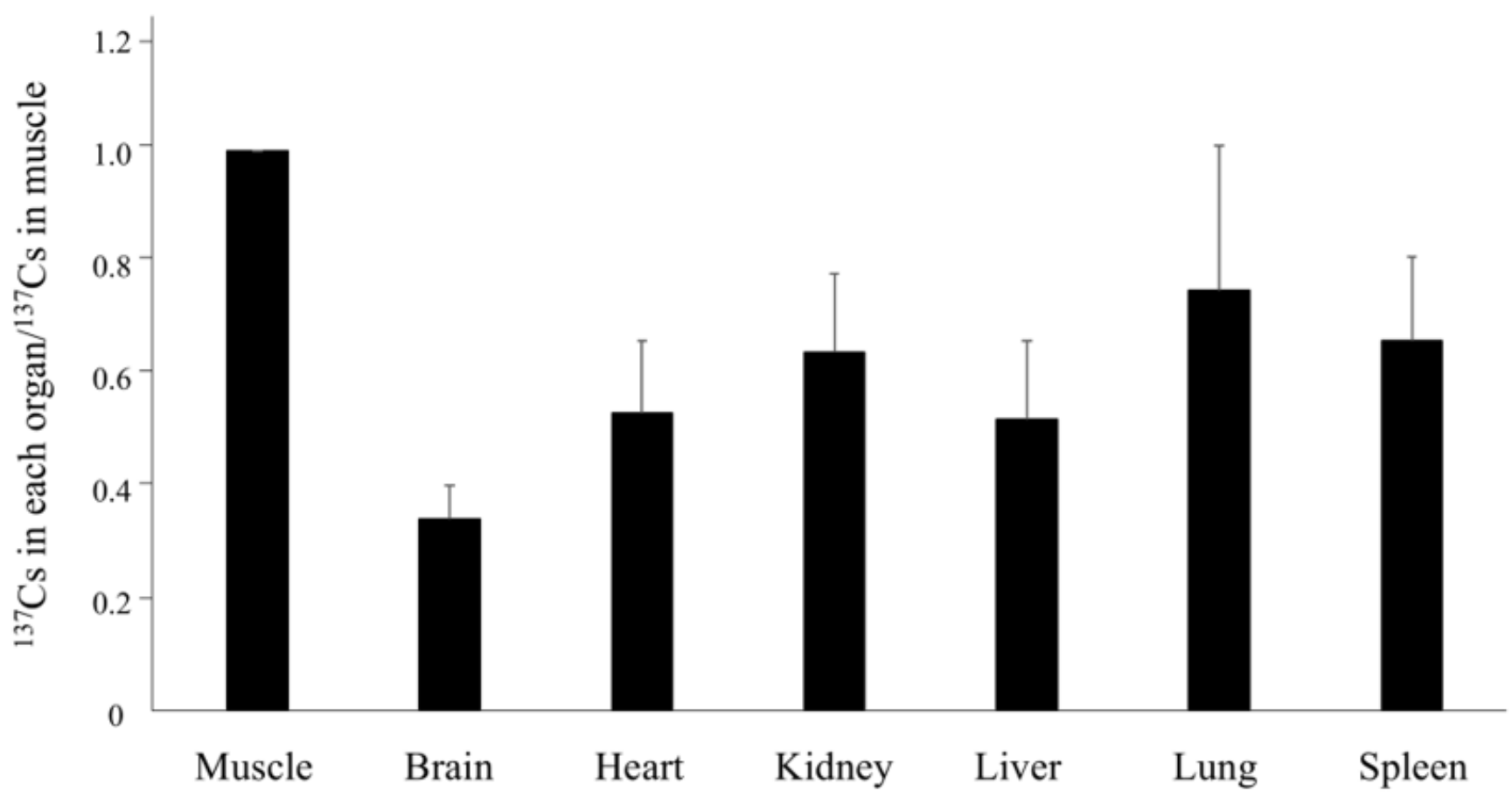

Fig. 1

\section{Figure 1}

Distribution of $137 \mathrm{Cs}$ in organ and tissue samples collected from 10 Japanese monkeys in 2012. Graph shows the ratio of the concentration of 137Cs in each organ to that in muscle (137Cs in each organ/137Cs in muscle). Error bars indicate SD. 